\title{
Elena Chibisova
}

\section{Economic Order and the Problems of Ruble: Regulatory Aspects}

\begin{abstract}
The problems of the Russian transformation are strongly related to the policy model adopted by the chief financial regulator, which in the case of this article is the Central Bank of Russia. It is argued here that the policy followed by the CBR is obsolete and rooted in the 1990s, and not up to date with the needs of the current economic conditions. These conditions are specific only to Russia and deserve the name of a "small cold war". The CBR continues to pursue a liberalisation policy based on concepts borrowed from the West. Their core is a complete liberalisation of the international currency flows, at the expense of protecting the domestic market from international speculative capital, and at the price of encouraging capital flow away from Russia. At the same time this policy has managed to discourage long term domestic investments.
\end{abstract}

Keywords: The Central Bank of Russia (the CBR), ruble, transition economy 


\section{Elena Chibisova}

\section{Porządek gospodarczy i problemy rubla. Aspekty regulacyjne}

\section{STRESZCZENIE}

Problemy rosyjskiej transformacji wynikają z modelu polityki przyjętej przez dyrektora nadzoru finansowego, którym w tym przypadku jest Centralny Bank Rosji (CBR). Polityka CBR jest przestarzała i zakorzeniona w latach 90. XX wieku, co nie przystaje do potrzeb obecnych warunków gospodarczych. Warunki te są specyficzne dla Rosji i zasługują na miano „małej zimnej wojny". CBR kontynuuje politykę liberalizacji w oparciu o zapożyczone z Zachodu pojęcia, których sednem jest całkowita liberalizacja przepływów waluty międzynarodowej-kosztem ochrony rynku krajowego przed międzynarodowym kapitałem spekulacyjnym i za cenę wypływu kapitału z Rosji. Jednocześnie polityka ta zniechęca do długoterminowych inwestycji krajowych.

Słowa kluczowe: Centralny Bank Rosji (CBR), rubel, gospodarka przejściowa 
The article is devoted to the problem of Russia's transition to the free financial market and the impact of this process on the position of the ruble. It argues that the current Russian economic order was inspired by the crisis of the 1990s and many of its provisions are not relevant today, because economic growth during the 2000s has radically changed the situation in the global and Russian economies. It is also argued that the Russian authorities continue the process of liberalization of the financial system despite national economic interests.

Russia has taken the course to a market economy in the early 1990s. A distinctive feature of the Russian transition from central planning to market economy was the policy of integration into the world economy while holding of status of the center of integration on the post-Soviet territories. Contrary to the Russian way, the Eastern bloc countries headed for the integration with the European Union. Russia has formed three circles of its foreign economic relations: the former republics of the USSR, the EU and partner countries from other regions. This structure of economic relations between Russia and the outside world was derived from the idea of modernization of its economy rooted in 1991. It was the idea that economic backwardness can be overcome by the import of institutions from the West simultaneously with the export of raw materials. The economic order in Russia rests on the idea of a rapid modernization that has implied the removal of the laws which restricted the free circulation of foreign currencies within the Russian territory and launching a freely convertible currency.

This paper argues that building a free currency market in Russia while maintaining, to some degree, an artificially low exchange rate of the ruble - vulnerable to the expansion of speculative capital on the Russian financial market - has produced negative effects. Several legislative acts which govern the domestic financial market will be invoked as an example of how the CBR follows the liberal economic order built in the 1990s in spite of the new policy aiming at the resurrection of the strong Russian state, an official policy effective since 2000. The policy of the CBR illustrates the limits promoting modernization as prescribed in the 1990s. It is believed that further research of both cooperation and collisions of the Russian institutions in the financial sphere is needed.

Research supported by experience shows that the constitutional functions of the Central Bank of Russia to defend ruble have become outdated and can't work effectively under the conditions of an anti-inflation policy based on the old methods in favor of keeping inflation on a low level by 
higher interest rates. The CBR is focusing on raising interest rates, as it has been doing for many years before 1990, struggling with the impact of the sanctions imposed by the West against Russia. CBR is trying to cope with the inflation employing a method appropriate for a different set of historical circumstances. It has clearly diverged from the actual problems of modern finance as observed by Sergey Glazev ${ }^{1}$.

The problem of the anti-inflation policy run by the CBR touches not only the old methods in providing monetary policy. This policy should also take into account the interests of holders of deposits and the chronic lack of savings in the Russian bank system, which entails the issue of the backup of the great credit volume in the Russian economy ${ }^{2}$.

The process of construction the free currency exchange and the creation of a stock market, which began in the early 1990s, has come into conflict with the method employed by the Central Bank to stop inflation through the periodical changes of interest rate. Foreign exchange interventions by the Central Bank of Russia had a limited and short-term effect, being obsolete in the current Russian conditions. The configuration of exchange market in Russia has determined the nature of the post-Soviet modernization.

The mode of political transformation as experienced in Russia in the post-Soviet period has led to the development of a specific structure of Russian external relations. In this system composed of three spheres of international relations the Russian currency should: 1) maintain trade relations between Russia and the European Union, 2) maintain trade between Russia and countries outside the EU and not part of the USSR, 3) maintain international transactions within the post-Soviet space. In all three spheres, the ruble is being exchanged either in reference to the euro or to the US dollar. Often the ruble is not treated as an independent currency even in the post-Soviet territories, today outside of Russia. However, the ruble could be a major reserve currency for Belarus, Kazakhstan, Tajikistan, Kyrgyzstan and Armenia, which might increase the value of the ruble. Such scenario has not materialized in practice because of the traditional systemic position of the Central Bank of Russia. Stable and expensive ruble is not viewed as beneficial for all economic agents in Russia.

1 S. Glazev, U.S. Sanctions and the Bank of Russia: double blow on the national economy, "Voprosy Ekonomiki", No. 9/2014, passim.

2 G. Popov, Combined crisis in Russia, "Terra Economicus", Vol. 12, No. 3/2014, passim. 
The main problem is that there are contradictions between the various spheres of external economic relations. Russia needs to increase the export of raw materials trading with the EU and it requires the undervaluation of the exchange rate, while the trade with the former Soviet republics requires high exchange rate of the ruble for buying raw materials and food. This contradiction is also valid for the Russian-Chinese trade relations, where Russia's trade with China is better off with an expensive ruble.

An undervalued ruble offers survival for uncompetitive companies thus protected (ruble becoming a protectionist barrier). In an analysis of this issue it has to be taken into account that the cost of Russian oil is still much higher than in Saudi Arabia. The cost of Russian oil from new deposits has risen to $\$ 24$ per barrel, including transport and organizational costs (overhead), keeping the average cost at approximately 35-40 dollars per barrel. With taxes consuming more than half of their income, Russian oil companies cannot reach a suitable level of profitability with the oil price pegged as low as 60 dollars per barrel. For example, one of the most successful Russian oil company "Rosneft" has paid 58\% of its revenue in 2013 in taxes. In consequence, the oil sector of Russia seriously expects an undervalued ruble.

The exchange rate in the former republics of the USSR is tied to the dollar or euro. The undervalued ruble creates obstacles for an international trade in the post-Soviet space, but it is an inevitable consequence of the Russian economic and regulatory order. Normal ruble turnover as a currency of international exchange in the post-Soviet area suffers difficulties, so the export for rubles is less profitable than the export for dollars and euros. For example, the ruble-denominated trade takes place between Russia and Belarus (2/3 of the ruble turnover abroad). Since the Russian authorities never regarded the ruble turnover outside of Russia as important, the control system over this process has been actually handed over into the hands of private banks and firms as reflected in the Russian-Chinese agreement concerning the exchange between Russia and China. This situation seems unacceptable on the assumption of necessity to turn the ruble into a valued currency for the international trade and possibly a reserve currency.

One of the main measures capable of containing the inflation in Russia has become the refinancing rate, which has been maintained at a traditionally high level. The CBR reduced the refinancing rate in 2009-2010 with the aim to retain further the deepening recession. However, this measure had a tendency to "inflate the credit bubble, the consequence of which would be a decrease in consumer demand". 
The liberal policy in the 2000 and in the following years has led to a complete liberalization of the Russian financial and foreign exchange markets about the year 2006 - which was a realization of the idea of modernization at the expense of the external incomes inflow. The Russian Ministry of Finance under the leadership of Alexei Leonidovich Kudrin severely limited budget expenses, which resulted in a low growth of aggregate demand. Mr. Kudrin sought to stop the inflation and to create a reserve of financial resources in case of a downturn in oil prices. Therefore, aggregate demand as a factor of an economic growth in Russia is still regarded by the official institutions of the state as a minor factor because of the uncertainty as to the competitiveness of the Russian economy. The fight against inflation in Russia only by monetary methods had been already obsolete in the beginning of the 2000s as inflation was caused by the distribution of incomes and rising process of raw material. However, the CBR and the Ministry of Finance continue to apply monetary methods.

The year 2006 was a watershed in the development of Russia's financial system and the formation of a liberal economic order. By 2006 Russia introduced legislative measures that completely liberated its financial market from state protectionism and removed the barriers shielding Russia against the international speculative capital. This was the result of a concept of economic development based on external factors. The law concerning obligatory licensing for capital transactions was repealed. According to that law non-residents had to open an account in authorized Russian banks to acquire the right to financial transactions on the territory of Russia. Also, abolished were the provisions of law concerning short-term loans received from non-residents. As a result, the liberalization of the Russian financial market in 2001-2006 had provoked a massive inflow of speculative capital, which was inspired, among other, by the high rate of refinancing and the regulation of the exchange rate by the Central Bank ${ }^{3}$.

Article 75 of the Russian Constitution determines the status of the Central Bank of Russia as the guarantor of the ruble stability. Therefore, the protection from inflation is not legally the main purpose of the CBR, but nevertheless, the CBR keeps fulfilling such a role. The idea to limit the CBR as prescribed in Article 75 goes back to the early 1990s, when Russia had a negative balance

3 D.I. Terlaje, Monetary regulation of the inflow of speculative capital in Russia, "Economic Sciences", No. 12/2010, passim. 
of payments and a large foreign debt. However, the situation has changed radically since 1999. Russia has regained a positive balance of payments, created a surplus in the state budget and has paid off its debt to the West and to the IMF.

World oil prices increased radically after 1999. Since that time the Russian ruble has been strongly dependent on the situation on the global oil market; in these conditions the main constitutional function of the Central Bank has been hollowed out, as the Central Bank is not able to influence the international markets. The Central Bank of Russia cannot effectively mitigate the negative effects of the falling oil prices. Historically, due to too strong tying of the ruble exchange rate to the price of oil, the market poorly responded to the currency interventions, which was caused by the unpredictable behavior of banks and households.

Article 75 seems very imposing, unfortunately it also collides with the legislation concerning the abolition of mandatory reserves to be maintained by the Russian banks should they receive loans from non-residents. Therefore, the CBR is limited in its ability to use administrative measures aimed to stabilize the national currency, and it has to rely mainly on foreign exchange intervention (effectively the implementation of the policy of dependence on gold and foreign currency reserves). Thus, Article 75 of the Constitution of the Russian Federation was rendered meaningless just because of lacking sufficient reserves of the Central Bank.

The abolition of additional bank reserves in the case of loans taken from non-residents was not necessary in economic conditions of 2000 and later, because Russia needed to be protected from the inflow of speculative capital in this period ${ }^{4}$. Reserve requirements on loans made by non-residents have not been given up in some Eastern European democracies. Russian economy, which had a positive balance of payments, suffered under legislative measures such as the abolition of restrictions on inflows of short-term foreign loans to the banking sector.

The growth of external liabilities in Russia was also stimulated in the last decade of the century by Article 269 of the Tax Code. According to its provisions, companies had the right, until 1 January 2011, to take a marginal amount of expenses on liabilities in foreign currency, at the level 15\%, which is lower than the level of liabilities expressed in rubles. Art. 269 of

4 Ibidem. 
the Tax Code turned out to be attractive to the Russian business, for it has encouraged firms to borrow from foreign banks. Since 2015 Art 269 has entered into force again. So the CBR has lost another effective tool in limiting the demand for foreign currency in Russia.

Art 269 does not affect the rules concerning the marginal costs on debt obligations with date of a loan's recovery. This makes the Russian market for non-residents very attractive as far as providing short-term loans is concerned, which will lead to the increased volatility of the ruble. The Tax Code of the Russian Federation, in general, does not motivate non-residents for a long-term investment in the Russian economy. Great volume of the short-term liabilities provoked in 2000th growth of investments in stocks, commodity production and trade, wherever a higher capital turnover takes place, while long-term projects in innovative production have remained less attractive.

Capital outflow from Russia before the political crisis in 2014 has a phenomenal character. The refinancing rate in Russia remains one of the highest in the world, but the capital keeps flowing out of the country. The downturn in the refinancing rate has only contributed to the growth of capital outflows. It means that a varying refinancing rate is not an effective method of financial policy in Russian conditions. It is asserted in this paper that closing costs and loan terms related to oil prices ${ }^{5}$ are more important in Russia than the refinancing rate.

An important feature of the economic order in Russia is that $90 \%$ of the export is not elastic vis-à-vis the rate of exchange. This results from the fact that the Russian oil and gas industry was supported by the state for many years, for it was the main source for the state revenue. So the rate of exchange in Russia is poorly connected with demand on foreign currency, which depends on the household income. The exchange rate in Russia has little influence on the demand for imported goods. A 10\% downturn in the oil prices created a $6 \%$ ruble devaluation. Therefore, a liberalization of the Russian financial system has proved to be useless. Thus Russia's experience may provide a valuable insight for the countries whose economies depend heavily on export of oil or gas.

5 M. Petranovic, And does Russia need a free ruble? Influence the policy of a free course to volatilely ruble, "Economic Policy", No. 4/2010, passim. 
There is a feeling in Russia that the financial markets are subservient, however the CBR has tried for many years to serve as a tool in the state's effort to protect the ruble from devaluation and, at the same time, to liberalize the Russian finance system, these two goals being on an obvious collision course. It is obvious, that the CBR major legislative and regulatory function is not working, because this function had been designed in another era and rooted in economic conditions incompatible with today's market reality. One can argue that the Russian economy is ruled now by priorities of general economic liberalization proclaimed as the new economic order in 1992. This observation is reflected in the above mentioned Art. 269 of the Tax Code.

As one can see, the Russian authorities which respond to the needs of the financial system by resorting to the liberal formulas do not take into account the political situation which deserves to be named "a small cold war". One could argue that this is the result of a continuous trend established in 1990ties when the Russian state developed the conditions for a collision of irreconcilable interests. Financial organizations opt for further liberalization of the economy, while the CBR has cast away the idea of building a post-Soviet currency market as it has rejected founding the Russia-China exchange sphere on a strong ruble. The CBR, centered on the issue of the financial back-up in the banking system and the growth of deposits, has failed to provide conditions for the ruble to go international.

\section{BIBLIOGR APHY}

Glazev S., U.S. Sanctions and the Bank of Russia: double blow on the national economy, "Voprosy Ekonomiki", No. 9/2014, passim.

Petranovic M., And does Russia need a free ruble? Influence the policy of a free course to volatilely ruble, "Economic Policy", No. 4/2010, passim.

Popov G., Combined crisis in Russia, "Terra Economicus", Vol. 12, No. 3/2014, passim.

Terlaje D.I., Monetary regulation of the inflow of speculative capital in Russia, "Economic Sciences", No. 12/2010, passim. 